\title{
Н.В. Рашкевич
}

Національний університет цฺивільного захисту України, Харків, Україна

\section{РОЗРОБКА КЕРУЮЧОГО АЛГОРИТМУ МЕТОДИКИ ПОПЕРЕДЖЕННЯ НАДЗВИЧАЙНИХ СИТУАЦЙ НА ПОЛІГОНІ ТВЕРДИХ ПОБУТОВИХ ВІДХОДІВ З ЛІКВІДАЦЙНИМ ЕНЕРГОСМНИМ ТЕХНОЛОГІЧНИМ УСТАТКУВАННЯМ}

Полігони твердих побутових відходів з урахуванням сучасних тенденцій розміщення на їх території інноваційних ліквідаційних технологій з різноманітним енергоємним технологічним устаткуванням становлять додаткову техногенну небезпеку, щзо вимагає вжиття комплексу заходів з попередження надзвичайних ситуацій. В залежності від розміщення зазначеного устаткування по відношенню до полігону можуть виникнути надзвичайні ситуачії каскадного типу внаслідок зсуву мас відходів з наступним вибухом біогазу. В роботі запропонований керуючий алгоритм методики попередження надзвичайних ситуацій. Алгоритм складається з двох етапів: перший етап полягає у визначені області ефективних рімень щзодо вибору фізичних параметрів масиву відходів з урахуванням стійкості схилів на зсув; другий етап обмежені поширення наслідків небезпеки зсуву масиву відходів на ліквідаційне енергоємне технологічне устаткування.

Ключові слова: полігон твердих побутових відходів, ліквідаційне енергоємне технологічне устаткування, надзвичайна ситуачія, вибух, зсув.

\section{Постановка проблеми}

В Україні та світі на полігонах твердих побутових відходів (ТПВ) або звалищах відомі чисельні випадки небезпечних подій, надзвичайних ситуацій (НС) пов'язаних 3 пожежами, зсувами великих мас відходів [1,2]. Основними наслідками небезпек були: значна площа поширення, велика кількість загиблих, постраждалих, осіб 3 порушенням умов життєдіяльності. Скорочення значень показників цих наслідків $є$ пріоритетним напрямком в діяльності Державної служби України 3 надзвичайних ситуацій (ДСНС України).

В країнах світу що розвиваються, у тому числі в Україні, на полігонах ТПВ спостерігаються тенденції впровадження технологічного устаткування для збору та утилізації біогазу, що становить небезпеку виникнення НС [3]. Необхідно зазначити, що сьогодні в Україні шляхи 3 попередження небезпеки на полігонах ТПВ визначені лише загальними підходами стосовно виключно пожежної безпеки як для будь-якого небезпечного об'єкту та не відображають складної специфіки виконання завдань, особливо 3 урахуванням наявності ліквідаційного енергоємного технологічного устаткування. Одним із напрямків попередження НC $є$ впровадження методик, які базуватимуться на сучасних досягненнях інформаційних технологій та відповідного їх математичного наповнення.
Таким чином, невирішеною частиною проблеми цивільного захисту $€$ відсутність механізмів протидії надзвичайним ситуаціям каскадного типу розповсюдження внаслідок зсуву схилу мас відходів з наступним вибухом біогазу на ліквідаційному енергоємному технологічному устаткуванні полігону твердих побутових відходів, а саме відповідного керуючого алгоритму.

\section{Аналіз останніх досліджень і публікацій}

Стійкість схилів на зсув - це функція багатьох факторів, кожен 3 яких відокремлено або у комбінації може привести до того, що механізм руйнування схилу досягне критичних умов [4]. Тому вибір причинних факторів вважається фундаментальним етапом в моделюванні сприйнятливості до втрати стійкості схилів [5]. Автори [6] до внутрішніх факторів нестабільності відносять властивості відходів та структурні особливості будови тіла полігону, до зовнішніх землетрус, дощ, рециркуляція фільтрату, земляні роботи, перевантаження.

Підходи до підвищення стійкості до зсувів включають плани землекористування, належну практику будівництва, системи оповіщення, забезпечення готовності і обізнаності населення, оцінку ризиків, бар'єри фізичного захисту [7]. Більша кількість моделей управління полігонів ТПВ зосереджені на цілях забезпечення екологічної безпеки у відповідності з екологічними нормами [8]. Продукти розкладання ТПВ є джерелом техногенно- 
екологічної небезпеки [9] та в умовах НС становлять додатковий ризик для життя та здоров'я фахівців підрозділів ДСНС України [10].

Найбільш відомим методом стабілізації схилів $\epsilon$ зміна його поверхні (зменшення висоти, корекція профілю) й посилення конструкцій, відведення надлишку вологи. Питання запобігання перезволоження за допомогою дренажних споруд розглянуті в роботі [11], ізоляції відходів від атмосфери в роботі [12], перерозподілу грунтових мас за допомогою перегородок в роботі [13], утримання зсувних мас підпірними стінками на етапі технічної реабілітації в роботі [14], будівництво берм [15].

Аналіз моделювання гідравлічних процесів [16, 17], утворення та розповсюдження біогазу [18], теплообміну $[19,20]$, руху звилищного грунту [21, 22] довів відсутність комплексних досліджень 3 оцінки ефективності функціонування полігону твердих побутових відходів у разі введення до його технологічного процесу додаткового ліквідаційного енергоємного технологічного устаткування.

В роботі [23] зазначено, що умовою ефективності попередження НС на полігоні ТПВ за пріоритетними наслідками кількість постраждалих $q_{1}$, кількість загиблих осіб $q_{2}$, кількість осіб 3 порушенням умов життєдіяльності $q_{3} \epsilon$ строге виконання системи рівнянь:

$$
\left\{\begin{array}{l}
q_{1}(\rho, w, T)<q^{06} \\
q_{2}(\rho, w, T)=0 \\
q_{3}(\rho, w, T) \leq q^{\text {об }}
\end{array}\right.
$$

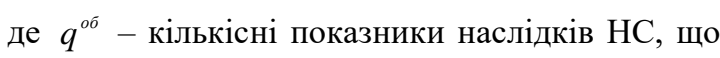
відповідають об'єктовому рівню; $(\rho, w, T)$ щільність, вологість, температура масиву відходів на полігоні ТПВ.

У зв'язку з цим, задача розробки керуючого алгоритму реалізації методики попередження надзвичайних ситуацій на полігоні твердих побутових відходів 3 ліквідаційним енергоємним технологічним устаткуванням $є$ актуальною у сфері цивільного захисту.

\section{Формулювання мети статті}

Метою роботи $\epsilon$ розробка керуючого алгоритму методики попередження надзвичайних ситуацій каскадного типу на полігонах твердих побутових відходів 3 ліквідаційним енергоємним технологічним устаткуванням внаслідок втрати стійкості схилу масиву відходів на зсув з наступним вибухом біогазу.

\section{Виклад основного матеріалу}

Зібраний біогаз 3 масиву полігону ТПВ підлягає утилізації. 3 огляду на економічну рентабельність, пряме енергетичне використання біогазу доцільне, якщо полігон ТПВ розташований поблизу кінцевого споживача (як правило, на відстані менше 10 або 15 км), або сам полігон $є$ споживачем енергії. Географічні обмеження долаються за допомогою використання біогазу для виробництва електроенергії безпосередньо на полігоні.

До основного ліквідаційного енергоємного технологічного устаткування для прямого використання біогазу відносяться котли для виробництва пару або гарячої води. Пар можна використовувати для обігріву приміщень, в промислових процесах або виробництві електроенергії за допомогою парових турбін. Печі різної конструкції та пристрої для сушки можуть використовувати біогаз, як основний або додатковий вид палива у виробничому процесі. Також відносяться інфрачервоні обігрівачі, випарники фільтрату.

Для виробництва електроенергії 3 біогазу, отриманого в умовах полігону ТПВ, використовують двигуни внутрішнього згоряння

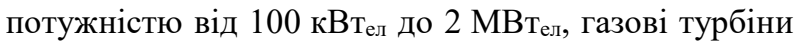
потужністю більше $4 \mathrm{MBT}_{\text {ел }}$, мікротурбіни потужністю до 100 кВтел. Деякі газові проекти по утилізації біогазу передбачають використання когенераційних установок - сумісне виробництво електричної та теплової енергії.

Вибір відповідного ліквідаційного енергоємного технологічного устаткування залежить від ряду факторів. В контексті попередження НC вагоме значення мають: кількісний та якісний склад біогазу, його зміни 3 часом; наявність поблизу полігону ТПВ кінцевого споживача для прямого використання; власні потреби в споживанні енергії; наявність та кваліфікація операторів.

Інформаційна модель процесу виникнення $\mathrm{HC}$ каскадного типу розповсюдження внаслідок зсуву схилу мас відходів з наступним вибухом біогазу в умовах наближеного розташування ліквідаційного енергоємного технологічного устаткування зображена на рисунку 1. Основними небезпечними факторами виникнення НС є зсув мас відходів на полігоні ТПВ - зона $\mathrm{HC}_{1}$, та вибух біогазу на ліквідаційному енергоємному технологічному устаткуванні - зона $\mathrm{HC}_{2}$. 


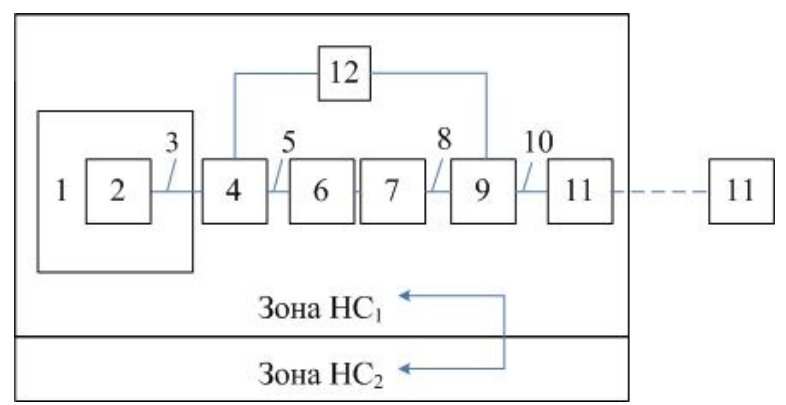

Рис. 1. Інформаційна модель процесу виникнення НС каскадного типу розповсюдження внаслідок зсуву схилу мас відходів з наступним вибухом біогазу в умовах наближеного розташування ліквідаційного енергоємного технологічного устаткування

На рисунку 1 використані визначення: 1 масив відходів, 2 - газові свердловини, 3 газозбірні трубопроводи з конденсатовідводчиками, 4 - газозбірна станція (колектори), 5 газотранспортний трубопровід низького тиску, 6 вузол підготовки, 7 - газокомпресорна станція, 8 газопровід високого тиску, 9 - ліквідаційне енергоємне технологічне устаткування, 10 розподільча мережа, 11 - кінцевий споживач, 12 система фізичного захисту.

Умови на полігоні ТПВ, 3 причин різної кількості, складу, віку відходів, інфільтрації повітря, атмосферних опадів тощо, постійно змінюються, а система збору біогазу, ліквідаційне енергоємне технологічне устаткування піддається стресам. Якщо ліквідаційне енергоємне технологічне устаткування розташовано поряд 3 полігон ТПВ, то існує ймовірність виникнення НС каскадного характеру. Небезпечні фактори впливу зсуву мас відходів на полігоні ТПВ можуть ініціювати вибух біогазу на ліквідаційному енергоємному технологічному устаткуванні, та навпаки, небезпечні фактори вибуху біогазу - зсув мас відходів.

На рисунку 2 зображені зона $\mathrm{HC}_{1}$ наслідок зсуву мас відходів на полігоні ТПВ та зона $\mathrm{HC}_{2}$ внаслідок вибуху біогазу на ліквідаційному енергоємному технологічному устаткуванні, які рознесені на безпечну відстань по відношенню один до одного. НС можуть виникнути i існувати незалежно у часі та територіально одна від одної каскадний характер виключений, поширення наслідків небезпеки обмежені. Зона $\mathrm{HC}_{1}$ охоплює масив відходів (1) та комунікації збору біогазу (газові свердловини (2), газозбірні трубопроводи 3 конденсатовідводчиками (3), газозбірну станцію (колектори) (4)). Зона $\mathrm{HC}_{2}$ - вузол підготовки (6), газокомпресорну станція (7), газопровід високого тиску (8), ліквідаційне енергоємне технологічне устаткування (9), розподільчу мережу (10). Кінцевий споживач (11) може відноситись до зони $\mathrm{HC}_{2}$ у випадку розміщення поряд 3 ліквідаційним енергоємним технологічним устаткуванням.

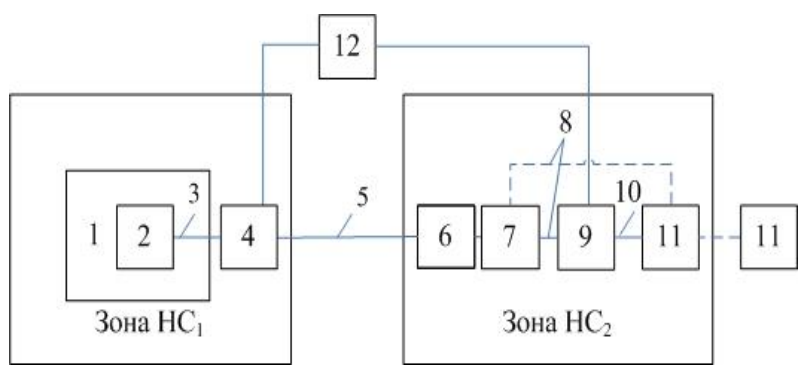

Рис. 2. Інформаційна модель процесу попередження

НС каскадного типу розповсюдження внаслідок зсуву схилу мас відходів з наступним вибухом біогазу

Наслідки НС $q_{1-3}$ пов'язані умовою вибору варіації рішень окремих задач 3 визначення щільності $\varphi_{1}$, вологості $\varphi_{2}$, температури $\varphi_{3}$ :

Математична модель попередження надзвичайної ситуації на полігоні ТПВ 3 ліквідаційного енергоємного технологічного устаткування має вид (2) та умови іiі існування (3) [23]:

$$
\begin{aligned}
& \left\{\begin{array}{l}
q_{2}(\rho, w, T)=0 \\
\Psi\left(q_{1}, q_{2}, q_{3}\right)=f_{q_{1}, q_{2}, q_{3}}\left(\varphi_{1}, \varphi_{2}, \varphi_{3}\right)
\end{array}\right. \\
& \left\{\begin{array}{l}
q_{1}(\rho, w, T)<q^{\text {об }} \\
q_{3}(\rho, w, T) \leq q^{\text {об }}
\end{array}\right.
\end{aligned}
$$

У відповідності до розробленої математичної моделі попередження надзвичайних ситуацій [23], керуючий алгоритм іiі реалізації в практичній діяльності наведений на рис. 3.

Керуючий алгоритм складається 3 двох етапів. 1 етап включає в себе визначення області ефективних рішень щодо вибору фізичних параметрів масиву відходів. На цьому етапі розраховуємо коефіцієнт стійкості схилу масиву відходів на зсув 3 врахуванням взаємовпливу на його стан показників вологості, щільності, температури. II етап - обмеження впливу технологічних показників додаткового ліквідаційного енергоємного устаткування на поширення наслідків небезпеки зсуву масиву відходів. На цьому етапі розраховуємо критичну відстань від схилу масиву відходів до ліквідаційного енергоємного технологічного устаткування. 


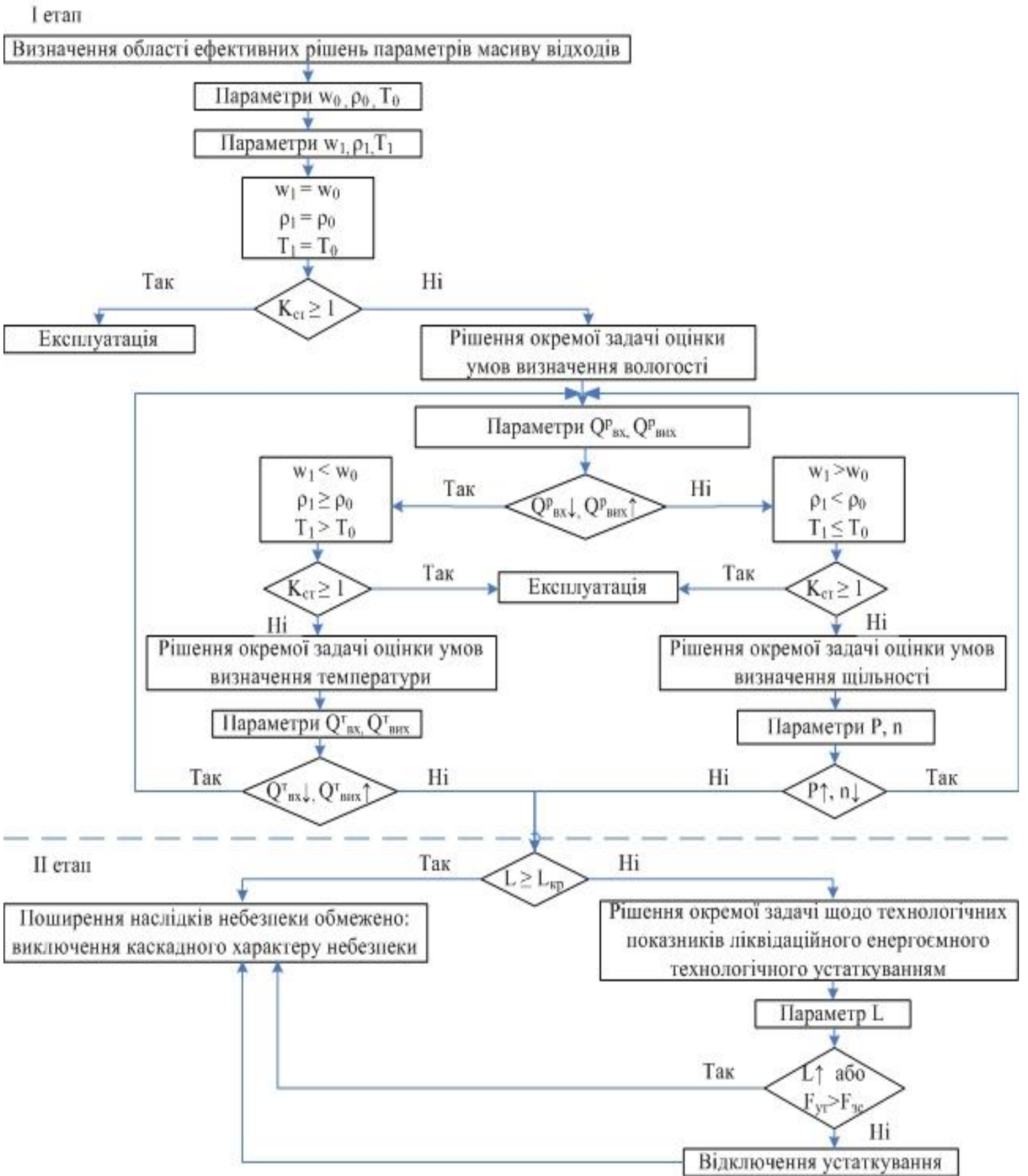

Рис. 3. Керуючий алгоритм реалізації математичної моделі попередження надзвичайних ситуацій каскадного типу на полігонах твердих побутових відходів з ліквідаційним енергоємним технологічним устаткуванням

Беручи до уваги прагнення отримати максимальну кількість метану у складі біогазу, на початку 1-го етапу алгоритму розглядаємо рівність фізичних показників області ефективних рішень щодо метаногенерації та область ефективних рішень щодо забезпечення стійкості схилу масиву відходів на зсув. При цьому, якщо опір масиву відходів на зсув перевищує або дорівнює зсувному зусиллю, можна стверджувати про безпечну експлуатацію потенційно небезпечного об’єкту - утилізацію біогазу в умовах полігону ТПВ.

До основних факторів метаногенерації належать температура в межах $30-40^{\circ} \mathrm{C}$, вологість в межах 60-80 \%. Додатковим фактором є щільність - чим вище щільність, тим менше газу утворюється [24, 25].

Якщо коефіцієнт стійкості масиву відходів на зсув менше 1, необхідно здійснювати заходи по збільшенню опору на зсув на основі вирішення окремих задач оцінки умов визначення вологості, щільності, температури масиву відходів 3 урахуванням взаємовпливу фізичних показників. Наприклад, зменшення вологості може призвести до збільшення температури, збільшення щільності.

Рішення окремої задачі оцінки умов визначення вологості масиву відходів являє собою аналітичну залежність, яка описує зв'язок вологості 
масиву у відповідності до варіації вхідних $Q_{b x}^{p}$ та вихідних потоків рідини $Q_{\text {sux }}^{p}$.

Рішення окремої задачі оцінки умов визначення щільності масиву відходів являє собою аналітичну залежність, яка описує зв'язок щільності масиву у відповідності до варіації фізичних параметрів - пористості масиву $n$, зовнішньої сили навантаження $P$.

Рішення окремої задачі оцінки умов визначення температури масиву відходів являє собою аналітичну залежність, яка описує зв'язок температури масиву у відповідності до варіації кількості тепла $Q_{6 x}^{T}$, що підводиться, утворюється внаслідок розкладання відходів та відводиться $Q_{\text {виx }}^{T}$.

Для досягнення мети попередження надзвичайних ситуацій каскадного типу на полігонах ТПВ 3 ліквідаційним енергоємним технологічним устаткуванням, внаслідок втрати стійкості схилу масиву відходів на зсув з наступним вибухом біогазу, в інтересах недопущення переростання надзвичайної ситуації з об'єктового на більш високі рівні поширення небезпеки, необхідно виконати ряд послідовно взаємопов'язаних способів та прийомів виконання робіт.

Таким чином, розроблено керуючий алгоритм реалізації математичної моделі попередження надзвичайних ситуацій каскадного типу на полігонах твердих побутових відходів 3 ліквідаційним енергоємним технологічним устаткуванням, внаслідок втрати стійкості схилу масиву відходів на зсув 3 наступним вибухом біогазу. Останній складається з 18 аналітичних блоків, які розміщено на двох рівнях та пов'язані між собою прямими та зворотними зв'язками.

3 метою його подальшого практичного застосування необхідна розробка відповідної методики, реалізація якої повинна ефективно протидіяти надзвичайній ситуації за пріоритетними наслідками, як то, кількість постраждалих, кількість загиблих, кількість осіб 3 порушенням умов життедіяльності.

\section{Висновки}

1. У ході роботи розглянуті фізичні умови попередження надзвичайної ситуації на полігоні твердих побутових відходів в умовах окремої задачі залучення ліквідаційного енергоємного технологічного устаткування. В залежності від розміщення зазначеного устаткування по відношенню до полігону твердих побутових відходів можуть виникнути надзвичайні ситуації каскадного типу внаслідок зсуву мас відходів 3 наступним вибухом біогазу.
2. У ході роботи розроблено керуючий алгоритм методики попередження надзвичайних ситуацій каскадного типу на полігонах твердих побутових відходів 3 ліквідаційним енергоємним технологічним устаткуванням внаслідок втрати стійкості схилу масиву відходів на зсув 3 наступним вибухом біогазу.

\section{Література}

1. Рашкевич, Н.В. Спосіб виявлення пожеж на територіі полігону твердих побутових відходів [Текст] / Н.В. Рашкевич, І.А. Черепньов, І.О. Ковальов // Інженерія природокористування. - 2019. - № 3 (13). - С. 102-109.

2. Lavigne, F., Wassmer, P., Gomez, C., Davies, T., Hadmoko, D.S., T Yan W M Iskandarsyah, ... Pratomo, I. (2014). The 21 February 2005, catastrophic waste avalanche at Leuwigajah dumpsite, Bandung, Indonesia. Geoenvironmental Disasters, 1,10

3. Рашкевич, Н.В. Аналіз техногенної небезпеки технологій поводження з твердими побутовими відходами [Текст] / Н.В. Рашкевич // Науково-технічний збірник «Комунальне господарство міст».. Серія: Технічні науки та архітектура. - 2019. - № 152. - C. 58-66.

4. Nejan Huvaj-Sarihan, Timothy D. Stark (2008). BackAnalyses of Landfill Slope Failures. International Conference on Case Histories in Geotechnical Engineering, 12.

5. Dou, J., Oguchi, T., Hayakawa, Y.S., Uchiyama, S., Saito, H., Paudel, U. (2014). Susceptibility Mapping Using a Certainty Factor Model and Its Validation in the Chuetsu Area, Central Japan. Landslide Sci a Safer Geoenvironment, 2, 483-489.

6. Huang, Y., Fan, G. (2016). Engineering geological analysis of municipal solid waste landfill stability. Natural Hazards, 84, 1 (6), 93-107.

7. Nadim, F., Lacasse, S. (2008). Landslide risk assessment and mitigation strategy. Landslides-disaster risk reduction. Springer, Berlin, Germany, 31-61.

8. Laner, D., Crest, M., Scharff, H., Morris, J.W.F., Barlaz, M.A. (2012). A review of approaches for the long-term management of municipal solid waste landfills. Waste Manag, 32, 498-512.

9. Рашкевич, Н.В. Дослідження небезпеки продуктів розкладання в місиях депонування твердих побутових відходів [Текст] / Н.В. Рашкевич, К.О. Цитлішвілі // Вісник КрНУ ім. М. Остроградського. - №3/2018(110). C. 97-102.

10. Вамболь, В.В. Анализ особенностей экологического мониторинга атмосферного воздуха в зоне чрезвычайных ситуаций техногенного характера [Текст] / В.В. Вамболь, А.С. Рашкевич, Н.В. Рашкевич // Вісник Національного технічного університету «ХПI». - 2016. № 49 (1221). - C. 85-89.

11. Illmer, D., Helgason, J.K., Jóhannesson, T., Gíslason, E., Hauksson, S. (2016). Report VÍ 2016-006. Overview of landslide hazard and possible mitigation measures in the settlement southeast of Fjarðará River in Seyðisfjörður. 75 p. 12. Sudheer, K.Y., Sunil, K., Sreedeep, S., Ravi, R.R. (2019). Determination of soil erosion index for surface soils of landfill covers. Environmental Geotechnics, 6, 6, 373380 .

13. Li, X., Yan, Q., Zhao, S. et al. (2020). Investigation of 
influence of baffles on landslide debris mobility by 3D material point method. Landslides.

14. Koda, E., Głażewski, M. (2006). Technical and biological reinforcement of rebuilt landfill slopes. Conference: 13th Danube-European Conference on Geotechnical Engineering At: Ljubljana. Volume: 2.

15. Biao Xia, Zhibiao Xiong, Chen Peng, Caiyun Zhang. (2016).The slope instability emergency rescue analysis when the neighboring deep the foundation pit retaining structure construction. Environment, Energy and Earth Sciences.

16. Schroeder, P.R., Dozier, T.S., Zappi, P.A., McEnroe, B.M., Sjostrom, J.W., Peyton, R.L. (1994). The Hydrologic Evaluation of Landfill Performance (HELP) Model. Engineering Documentation for Version 3. EPA/600/R94/168b. U.S. Environmental Protection Agency; Cincinnati, $\mathrm{OH}, \mathrm{USA}$.

17. Методика расчета водного баланса полигонов захоронения твердых бытовых отходов [Текст] / Я.И. Вайсман, М.А. Тагилов и др. - Пермь, 2002. - 19 c.

18. Rashkevich, N., Goncharenko, I., Anishenko, L. et al. (2018). Biogas from the municspal solid waste polygon. Scientific Journal «ScienceRise», 9 (50), 39-42.

19. Левин, В.А. Моделирование двумерных нестационарных течений газа в саморазогревающихся полигонах твердых бытовых отходов [Текст] / В.A. Левин, Н.А. Луиенко // Вычислительная механика сплошных сред. - 2011. - Т. 4. - № 1. - С. 55-64.

20. Середа, Т.Г. Решение контактной задачи теплопроводности для полигона твердых бытовых отходов [Текст] / Т.Г. Середа // Фундаментальные исследования. - 2014. - № 12-5. - С. 936-940.

21. Офрихтер, В.Г. Реологическая модель твердых бытовых отходов [Текст] / В.Г. Офрихтер, Н.Н Лихачева // Известия КГАСУ. - 2013. - № 4 (26). - С. 161169.

22. Brinkgreve, R.B.J., Broere, W., Waterman, D. (2008). Plaxis 2D-version 9. Finite Element Code for Soil and Rock Analyses. User Manual. 2009th ed.Rotterdam: Balkema.

23. Рашкевич, Н.В. Формування математичного апарату методики попередження надзвичайної ситуачії на полігоні твердих побутових відходів з технологічним устаткуванням [Текст] / Н.В. Рашкевич // Науковотехнічний збірник «Комунальне господарство міст». Серія: Технічні науки та архітектура. - 2020. - № 154. C. 100-107.

24. Проект Тасис - Совериенствование системы управления твердыми бытовыми отходами в Донецкой области Украины. Пособие по мониторингу полигонов ТБО. Thales E\&C-GKW-Consult. - 2004. - 271 c.

25. Шаимова, А.М. Изучение факторов метангенерации в условиях полигона твердых бытовых отходов [Текст] / А.М. Шаимова, Л.А. Насырова, Р.Р. Фасхутдинов // Башкирский химический журнал. -2011. - T. 18. - № 2. C. 172-176.

\section{References}

1. Rashkevich, N.V, Cherepnev, I.A., Kovalev, I.O. (2019). Method of fire detecting at a municipal solid waste landfill. Engineering of nature management, Seriya: Tekhnichni nauky ta arkhitektura, 3 (13), 102-109.

2. Lavigne, F., Wassmer, P., Gomez, C., Davies, T., Hadmoko, D.S., T Yan W M Iskandarsyah, ... Pratomo, I.
(2014). The 21 February 2005, catastrophic waste avalanche at Leuwigajah dumpsite, Bandung, Indonesia. Geoenvironmental Disasters, 1, 10.

3. Rashkevich, N.V. (2019). Analysis of technogenic danger of solid waste management technologies. Naukovotekhnichnyy zbirnyk «Komunal'ne hospodarstvo mist», 152, 58-66.

4. Huvaj-Sarihan, Nejan, Stark, Timothy D. (2008). BackAnalyses of Landfill Slope Failures. International Conference on Case Histories in Geotechnical Engineering. 12.

5. Dou, J., Oguchi, T., Hayakawa, Y.S., Uchiyama, S., Saito, H., Paudel, U. (2014). Susceptibility Mapping Using a Certainty Factor Model and Its Validation in the Chuetsu Area, Central Japan. Landslide Sci a Safer Geoenvironment, 2, 483-489.

6. Huang, Y., Fan, G. (2016). Engineering geological analysis of municipal solid waste landfill stability. Natural Hazards, 84, 1 (6), 93-107.

7. Nadim, F., Lacasse, S. (2008). Landslide risk assessment and mitigation strategy. Landslides-disaster risk reduction. Springer, Berlin, Germany, 31-61.

8. Laner, D., Crest, M., Scharff, H., Morris, J.W.F., Barlaz, M.A. (2012). A review of approaches for the long-term management of municipal solid waste landfills. Waste Manag, 32, 498-512.

9. Rashkevich, N.V., Tsitlíshvílí, K.O. (2018). Study of influences of dangerous products decomposition from municipal solid waste. Visnyk KrNU im. M. Ostrohrads'koho, 3/2018(110), 97-102.

10. Vamol, V., Rashkevich, A., Rashkevich, N. (2016) An analysis of features of the ecological monitoring of atmospheric air is in the zone of emergencies of technogenic character. Bulletin of NTU "KhPI”, 49 (1221), 85-89.

11. Illmer, D., Helgason, J.K., Jóhannesson, T., Gíslason, E., Hauksson, S. (2016). Report VÍ 2016-006. Overview of landslide hazard and possible mitigation measures in the settlement southeast of Fjarðará River in Seyðisfjörður. 75 p.

12. Sudheer, K.Y., Sunil, K., Sreedeep, S., Ravi, R.R. (2019). Determination of soil erosion index for surface soils of landfill covers. Environmental Geotechnics 6, 6, 373-380.

13. Li, X., Yan, Q., Zhao, S. et al. (2020). Investigation of influence of baffles on landslide debris mobility by 3D material point method. Landslides.

14. Koda, E., Głażewski, M. (2006).Technical and biological reinforcement of rebuilt landfill slopes. Conference: 13th Danube-European Conference on Geotechnical Engineering At: Ljubljana. Volume: 2

15. Biao Xia, Zhibiao Xiong, Chen Peng, Caiyun Zhang. (2016).The slope instability emergency rescue analysis when the neighboring deep the foundation pit retaining structure construction. Environment, Energy and Earth Sciences.

16. Schroeder, P.R., Dozier, T.S., Zappi, P.A., McEnroe, B.M., Sjostrom, J.W., Peyton, R.L. (1994). The Hydrologic Evaluation of Landfill Performance (HELP) Model. Engineering Documentation for Version 3. EPA/600/R94/168b. U.S. Environmental Protection Agency; Cincinnati, $\mathrm{OH}$, USA.

17. Vaysman, Ya.I., Tagilov M.A. i dr. (2002). Metodika rascheta vodnogo balansa poligonov zakhoroneniya tverdykh bytovykh otkhodov, 19. 
18. Rashkevich, N., Goncharenko, I., Anishenko, L. et al. (2018). Biogas from the municspal solid waste polygon. Scientific Journal «ScienceRise», 9 (50), 39-42.

19. Levin, V.A., Lutsenko, N.A. (2011). Modelirovaniye dvumernykh nestatsionarnykh techeniy gaza $\mathrm{v}$ samorazogrevayushchikhsya poligonakh tverdykh bytovykh otkhodov. Vychislitel'naya mekhanika sploshnykh sred, 4, 1, 55-64.

20. Sereda, T.G. (2014). Resheniye kontaktnoy zadachi teploprovodnosti dlya poligona tverdykh bytovykh otkhodov. Fundamental'nyye issledovaniya, 12-5, 936-940.

21. Ofrikhter, V.G., Likhacheva, N.N. (2013). Reologicheskaya model' tverdykh bytovykh otkhodov. Izvestiya KGASU, 4 (26), 161-169.

22. Brinkgreve, R.B.J., Broere, W., Waterman, D. (2008). Plaxis 2D-version 9. Finite Element Code for Soil and Rock Analyses. User Manual. 2009th ed.Rotterdam: Balkema.

23. Rashkevich, N.V. (2020). Formation of mathematical apparatu for the methodology of emergency prevention on solid waste landfill with technological equipment. Naukovotekhnichnyy zbirnyk «Komunal'ne hospodarstvo mist, Seriya: Tekhnichni nauky ta arkhitektura, 154, 100-107.
24. Proyekt Tasis- Sovershenstvovaniye sistemy upravleniya tverdymi bytovymi otkhodami v Donetskoy oblasti Ukrainy. Posobiye po monitoringu poligonov TBO. (2004). Thales E\&C - GKW - Consult, 271.

25. Shaimova, L.A., Nasyrova, M.A., Faskhutdinov, R.R. (2011). Izucheniye faktorov metangeneratsii $\mathrm{v}$ usloviyakh poligona tverdykh bytovykh otkhodov. Bashkirskiy khimicheskiy zhurnal, 18, 2, 172-176.

Рецензент: д.т.н., с.н.с., начальник наукового відділу проблем цивільного захисту та техногенноекологічної безпеки науково-дослідного центру P. I. Шевченко, Національний університет цивільного захисту України, Харків, Україна.

\author{
Автор: РАШКЕВИЧ Ніна Владиславна \\ acnipaнm \\ Національний університет циивільного захисту \\ України \\ E-mail-nine291085@gmail.com \\ ID ORCID: http://orcid.org/0000-0001-5124-6068
}

\section{DEVELOPMENT OF THE CONTROL ALGORITHM OF THE METHODOLOGY OF EMERGENCY PREVENTION ON LANDFILL WITH LIQUIDATION ENERGY-INTENSIVE TECHNOLOGICAL EQUIPMENT \\ N. Rashkevich}

National University of Civil Defence of Ukraine, Kharkiv, Ukraine

Landfills taking into account current trends in the placement of innovative liquidation technologies on their territory with a variety of energy-intensive technological equipment pose an additional technogenic danger. This requires a set of measures to prevent emergencies of the cascade type of distribution, due to the shift of the slope of the waste masses with the subsequent explosion of biogas.

Analysis of existing approaches to modeling the conditions of solid waste landfills proves the lack of comprehensive studies to assess the effectiveness of solid waste landfills in the case of the introduction of additional technological energy-intensive technological equipment.

In the course of the work the author considers the physical conditions of emergency prevention at the landfill in the conditions of a separate task of involving liquidation energy-intensive technological equipment. Depending on the location of the specified equipment in relation to the landfill, emergencies of cascade type may occur due to the shift of waste masses with the subsequent explosion of biogas.

In the course of the work the author developed a control algorithm for the implementation of a mathematical model of cascade type emergency prevention at solid waste landfills with liquidation energy-intensive technological equipment due to loss of stability of the slope of the waste array to landslide followed by biogas explosion. The control algorithm consists of 18 analytical blocks, which are located on two levels and are interconnected by direct and feedback. In order to further practical application of the control algorithm, it is necessary to develop an appropriate methodology, the implementation of which should effectively counteract the emergency situation with priority consequences, such as the number of victims, the number of deaths, the number of people with impaired living conditions.

Keywords: landfill, emergency prevention, liquidation energy-intensive technological equipment, explosion, landslide 